\title{
Effects of Tetracycline and Temperature on Drosophila melanogaster Infected with Wolbachia Inducing the Popcorn-Effect
}

\author{
ENDANG SRIMURNI KUSMINTARSIH
}

\author{
Faculty of Biology, Universitas Jenderal Soedirman, Jalan Dr Soeparno 63 Grendeng, Purwokerto 53122, Indonesia
}

The expression of cytoplasmic incompatibility, parthenogenesis, and feminization in many hosts of Wolbachia is influenced by environmental factors such as temperature and antibiotics. Therefore, it might also affect Wolbachia inducing popcorn-effect. To examine the effects of temperature and antibiotic treatment on the life span of Drosophila melanogaster harbouring the popcorn-effect inducing strain of Wolbachia, flies were reared in different temperature such as at 20 and $29{ }^{\circ} \mathrm{C}$, and cultured (from egg to adult stage) on a medium containing tetracycline. The tetracycline-treated Wolbachia was established by placing $0.25 \mathrm{mg} \mathrm{mL}^{-1}$ of tetracycline in the media. The result showed that there was no difference in the life span of $D$. melanogaster infected with Wolbachia popcorn-effect under untreated and treated condition with tetracycline at $20{ }^{\circ} \mathrm{C}$. Therefore, there is no popcorn-effect in the D. melanogaster at low temperature $\left(20^{\circ} \mathrm{C}\right)$. While the life span of $D$. melanogaster at $29^{\circ} \mathrm{C}$, where infected flies have a shorter life span than treated flies. Popcorn-effect (shorter life span) was found at $29^{\circ} \mathrm{C}$.

Key words: cytoplasmic incompatibility, feminisation, parthenogenesis, popcorn-effect, tetracycline

Ekspresi ketidakserasian sitoplasma, partenogenesis, dan feminisasi pada beberapa inang yang terinfeksi Wolbachia dipengaruhi oleh faktor lingkungan seperti suhu dan antibiotik. Oleh karena itu, faktor-faktor tersebut kemungkinan juga berpengaruh pada Wolbachia penyebab efek-popcorn. Untuk menguji pengaruh suhu dan antibiotik terhadap lama hidup Drosophila melanogaster yang mengalami efek-popcorn yang disebabkan oleh infeksi Wolbachia, lalat-lalat tersebut dipelihara pada suhu $20^{\circ} \mathrm{C}$ dan $29^{\circ} \mathrm{C}$, kemudian dikultur dari stadium telur sampai menjadi dewasa pada media baik yang mengandung tetrasiklin $\left(0,25 \mathrm{mg} \mathrm{mL}^{-1}\right)$ maupun yang tidak mengandung tetrasiklin. Hasil menunjukkan bahwa antara lalat terinfeksi Wolbachia efek-popcorn yang diberi pengobatan maupun yang tidak diobati pada suhu $20^{\circ} \mathrm{C}$, tidak ada perbedaan dalam lama hidupnya. Oleh karena itu, tidak ada pengaruh efek-popcorn terhadap D. melanogaster pada suhu $20^{\circ} \mathrm{C}$. Lama hidup D. melanogaster pada suhu $29^{\circ} \mathrm{C}$ yang terinfeksi Wolbachia lebih pendek dibandingkan dengan yang diberikan tetrasiklin. Dengan kata lain terjadi efek-popcorn pada suhu $29^{\circ} \mathrm{C}$.

Kata kunci: efek-popcorn, feminisasi, ketidakserasian sitoplasma, partenogenesis, tetrasiklin

Wolbachia pipientis is common bacterial endosymbiont of arthropods and filarial nematodes; they are maternally inherited, obligate, and intracellular bacteria (McGraw et al. 2002). Interest in Wolbachia stems not only from its widespread distribution in arthropods, but also from the alterations of the mode of reproduction of its hosts caused by the bacteria uch as cytoplasmic incompatibility (CI), feminization (F), parthenogenesis (P), male killing and the popcorn-effect (Yu Peng et al. 2008; Carrington et al. 2010). The expression of cytoplasmic incompatibility, feminization, and parthenogenesis also density in many hosts of Wolbachia is influenced by environmental factors such as antibiotic and temperature (Mouton et al. 2007; Zhukova et al.2008; Jia et al. 2009; Suh et al. 2009).

Breeuwer and Werren (1993) reported that tetracycline treatment $\left(1 \mathrm{mg} \mathrm{mL}^{-1}\right.$ in $10 \%$ sucrose $)$ on

*Corresponding author; Phone: +62-281-638794, Fax: 62281-631700,E-mail: endang_sk@lycos.com female Nasonia vitripennis infected with Wolbachia induced cytoplasmic incompatibility which had a dramatic effect on bacterial densities in their eggs. On the first day after treatment, tetracycline had effectively eliminated cytoplasmic bacteria and caused reduction or absent of the microorganism in the eggs. Werren and Jaenike (1995) reported that in Drosophila recens, Wolbachia was lost with 0.2 and/or $0.25 \mathrm{mg}$ tetracycline per $\mathrm{ml}$ within two to three generations. However, $0.1 \mathrm{mg}$ tetracycline per $\mathrm{ml}$ apparently was not effective in curing the flies of Wolbachia. Kambhampati et al. (1993) showed that tetracycline treatment of Aedes albopictus results a partial, but significant restoration of compatibility.

Stouthamer et al. (1990) investigated Trichogramma harbouring parthenogenesis-inducing Wolbachia. When it was cured by antibiotics tetracycline hydrochloride, sulfamethoxazole or rifampicin (100mg $\mathrm{mL}^{-1}$ honey) the result was the appearance of male offspring because the microorganisms responsible for 
the lytoky were killed. However, treated with gentamycin, penicillin $G$ and erythromycin, Trichogramma male offspring did not occur. When Trichogramma reared at an elevated temperature $>30$ ${ }^{\circ} \mathrm{C}$, the females produced male offspring as well. Stouthamer et al. (1993) reported that antibiotic treatment of Trichogramma deion, T. pretiosum, $T$. cordubensis, and Mucidifurax uniraptor resulted in reversion to sexual reproduction and elimination of the microorganisms. Stevens (1989) reported that when larvae of Tribolium confusum were reared at $37^{\circ} \mathrm{C}$, the compatibility was partly restored because some larvae become cured of the infection with Wolbachia. Subsequently Stevens and Wicklow (1992) reported that tetracycline-producing Streptomyces and Penicillium can cure Tribolium flour beetles of infection with Wolbachia. Fujii et al. (2001) reported feminisationinducing Wolbachia in Ephestia kuehniella. Those cured by tetracycline produced male offspring. In original work on the $w$ MelPop strain in Drosophila melanogaster by Min and Benzer (1997), all infected flies held at $29{ }^{\circ} \mathrm{C}$ died within $14 \mathrm{~d}$. However, when longevity was assessed at $25{ }^{\circ} \mathrm{C}$, infected flies lived twice as long, suggesting that the virulence of $w$ MelPop depended on temperature (Carrington et al. 2009)

Trpis et al. (1981) reported evidence for suppression of CI with high temperature in several species. For example, in the mosquito Aedes scutellaris crosses between strains that are normally incompatible became compatible when larvae were raised at a temperature of $32.5{ }^{\circ} \mathrm{C}$. Hoffmann et al. (1986) reported that rearing larvae at $28^{\circ} \mathrm{C}$ the incompatibility of Drosophila simulans R (riverside) males and W (watsonville) females could be suppressed. Stevens (1989) reported that when larvae of T. confusum were reared at $37^{\circ} \mathrm{C}$, the compatibility was partly restored because some larvae become cured of the infection with Wolbachia.

Previous experiments showed that reproduction abnormalities such as cytoplasmic incompatibility, feminization, and parthenogenesis in many hosts of Wolbachia are influenced by environmental factors such as temperature and antibiotics. Therefore, it might also affect Wolbachia inducing popcorn-effect. To determine the possible role of the environment on the popcorn-effect inducing Wolbachia, D. melanogaster infected with Wolbachia popcorn-effect will be cured with $0.25 \mathrm{mg} \mathrm{mL}^{-1}$ tetracycline (as in the previous experiment by Min and Benzer, 1997) and reared at 20 and $29{ }^{\circ} \mathrm{C}$. The temperature of $20{ }^{\circ} \mathrm{C}$ is a close approximation of the optimal physiological temperature of D. melanogaster and the temperature at which the originally popcorn-effect was found is $29^{\circ} \mathrm{C}$.

\section{MATERIALS AND METHODS}

Analyses of the Effect of Antibiotic Treatment. D. melanogaster infected with Wolbachia inducing popcorn-effect obtained from the lab of Henk R Braig, School of Biological Sciences, University Of Wales, Bangor, United Kingdom. To examine the effect of antibiotic treatment, flies were cultured (from egg to adult stage) on a medium containing tetracycline. The tetracycline-treated strain was established by placing $0.25 \mathrm{mg} \mathrm{mL}^{-1}$ of tetracycline in the media. The strain was treated for three generation and tested for infection status with PCR, utilizing $81 \mathrm{~F}$ and 691R primers, specific for the wsp gene of Wolbachia (Braig et al. 1998). After adults emerged the male and female flies were reared separately at a density of 15 flies per vial (2.3 cm diameter and $9.5 \mathrm{~cm}$ in length) with 10 replicates. To examine the effect of temperature, flies were reared in different temperature such as at 20 and $29^{\circ} \mathrm{C}$.

Statistical Analysis. An effect of tetracycline and temperature in D. melanogaster infected with Wolbachia popcorn-effect would be manifest by its life-span. Univariate analysis of variance (SPSS 10.1) was used to determine the influence of temperature and tetracycline treatment. In order to apply ANOVA, the experimental data need to show a normal distribution and an equal variability. This is not the case in these experiments. The data therefore had to be transformed before a valid statistical analysis was possible. Several transformation methods were tested including using the square root of the raw data. Only the transformation of the raw data to their decimal logarithm was able to satisfy the requirements of ANOVA.

\section{RESULTS}

The effect of tetracycline on the Wolbachia inducing popcorn-effect was analysis by PCR and the results showed the untreated sample has band that positive for Wolbachia (lane 1 and 2 of Fig 1, Fig 2). However, treated treated samples has no visible band (lane 3, 4, 5, and 6, Fig 1), which indicates that Wolbachia was not exist any longer .

When D. melanogaster larvae untreated and treated with tetracycline were reared at different temperature, the life-span varied. Flies reared at $29^{\circ} \mathrm{C}$ exhibited a shorter life-span when they were infected with Wolbachia than 
flies treated with tetracycline (Fig 3). The difference in life-span was highly significant. However, there was no significant difference in sex (male and female).

Fig 4 shows that there is no difference in the life span of $D$. melanogaster between untreated and treated. Unlike the life span of D. melanogaster at 29

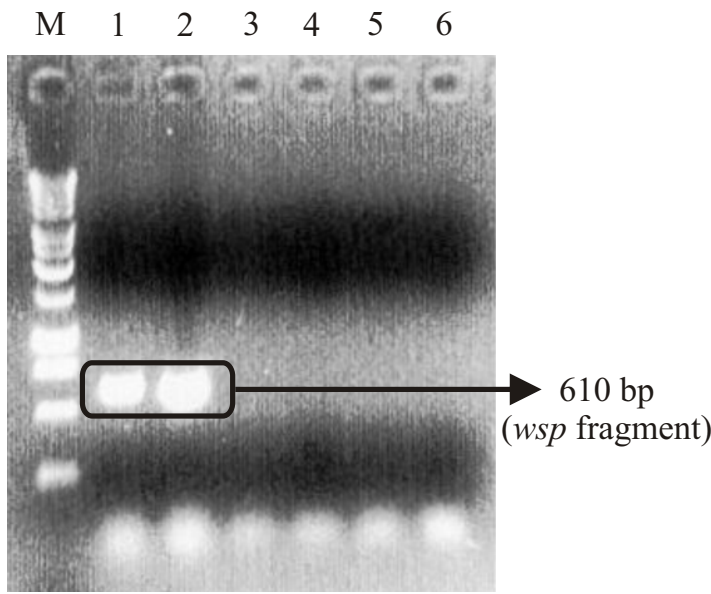

Fig 1 Detection of infection of Drosophila melanogaster (W1118) by Wolbachia untreated and treated with tetracycline. M: one kilobase ladder; 1 and 2: $D$. melanogaster (W1118) untreated; 3, 4, 5, 6: D. melanogaster (W1118) treated with tetracycline.

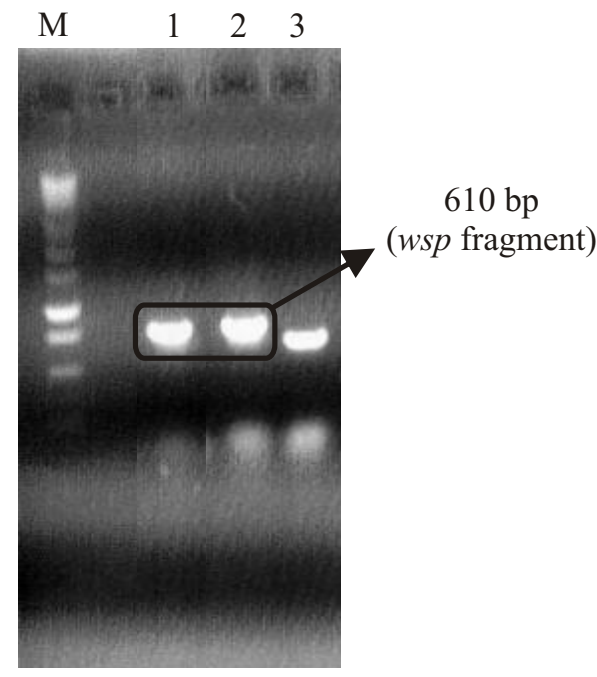

Fig 2 Detection of infection of Drosophila melanogaster (W1118) by Wolbachia untreated with tetracycline at 29 and $20{ }^{\circ} \mathrm{C}$. M: one kilobase ladder; 1: $D$. melanogaster infected with popcorn-effect maintained at $29{ }^{\circ} \mathrm{C} ; 2$ : D. melanogaster infected with popcorneffect maintained at $20{ }^{\circ} \mathrm{C}$; Line 3: positive control (amplification of ribosomal of nucleus of $D$. melanogaster infected with popcorn-effect at $20^{\circ} \mathrm{C}$ ).

${ }^{\circ} \mathrm{C}$ where infected flies have a shorter life span than treated flies. Therefore, there is no popcorn-effect in the $D$. melanogaster at low temperature $\left(20^{\circ} \mathrm{C}\right)$.

The analysis shows highly significant difference $(<$
0.001) between treatment (treated and untreated) at temperature $\left(29\right.$ and $20^{\circ} \mathrm{C}$ ). However, there is no significant difference between treatment and sex (male and female). At $20^{\circ} \mathrm{C}$ untreated and treated are not significant different. However, at $29^{\circ} \mathrm{C}$ untreated and treated are significant different.

\section{DISCUSSION}

When D. melanogaster larvae untreated and treated with tetracycline were reared at different temperature, the life-span varied. Flies reared at $29^{\circ} \mathrm{C}$ exhibited a shorter life-span when they were infected with Wolbachia than flies treated with tetracycline (Fig 3). The difference in life-span was highly significant. However, there was no significant difference in sex (male and female).

Tetracycline eliminated Wolbachia and restored the life-span of male and female flies at $29^{\circ} \mathrm{C}$. This was the same temperature for which the popcorn-effect of Wolbachia was originally described (Min and Benzer, 1997). Whereas when reared at $20^{\circ} \mathrm{C}$ (Fig 4) the life span of the flies was no longer significantly different between untreated and treated, although Wolbachia could still be detected when the flies were reared at 20 ${ }^{\circ} \mathrm{C}$ (Fig 2). Therefore, apparently there was no popcorn-effect at $20^{\circ} \mathrm{C}$. It was probably that at $20^{\circ} \mathrm{C}$ both host and bacteria function optimally, therefore no changes in life history parameters of fitness. In other words, the host perfectly controlled the bacteria under optimal physiological condition and Wolbachia did not disrupt the symbiotic relationship. Werren (1997) and McGraw et al. $(2001,2002)$ tried to explain the virulence of the popcorn-effect as an 'over-replication' of these bacteria. McGraw et al. (2002) investigated the question whether the popcorn-effect might reflect the initial increased virulence commonly observed in new host-parasite associations. They transferred the popcorn-effect Wolbachia into a new, naive host, $D$. simulans, where indeed early on reproductive fitness costs were noted caused by initial high densities of Wolbachia in the ovaries that were in excess of what was required for perfect maternal transmission. These fitness costs rapidly declined in the generations after transinfection. However, the popcorn-effect was practically independent of the observed attenuation of virulence. The authors reared the transinfected $D$. simulans at $26{ }^{\circ} \mathrm{C}$ in order to observe the popcorneffect. In our hands, a temperature of $29^{\circ} \mathrm{C}$ have been deadly already for uninfected $D$. simulans flies. The authors failed to make any observations at physiological temperatures. 


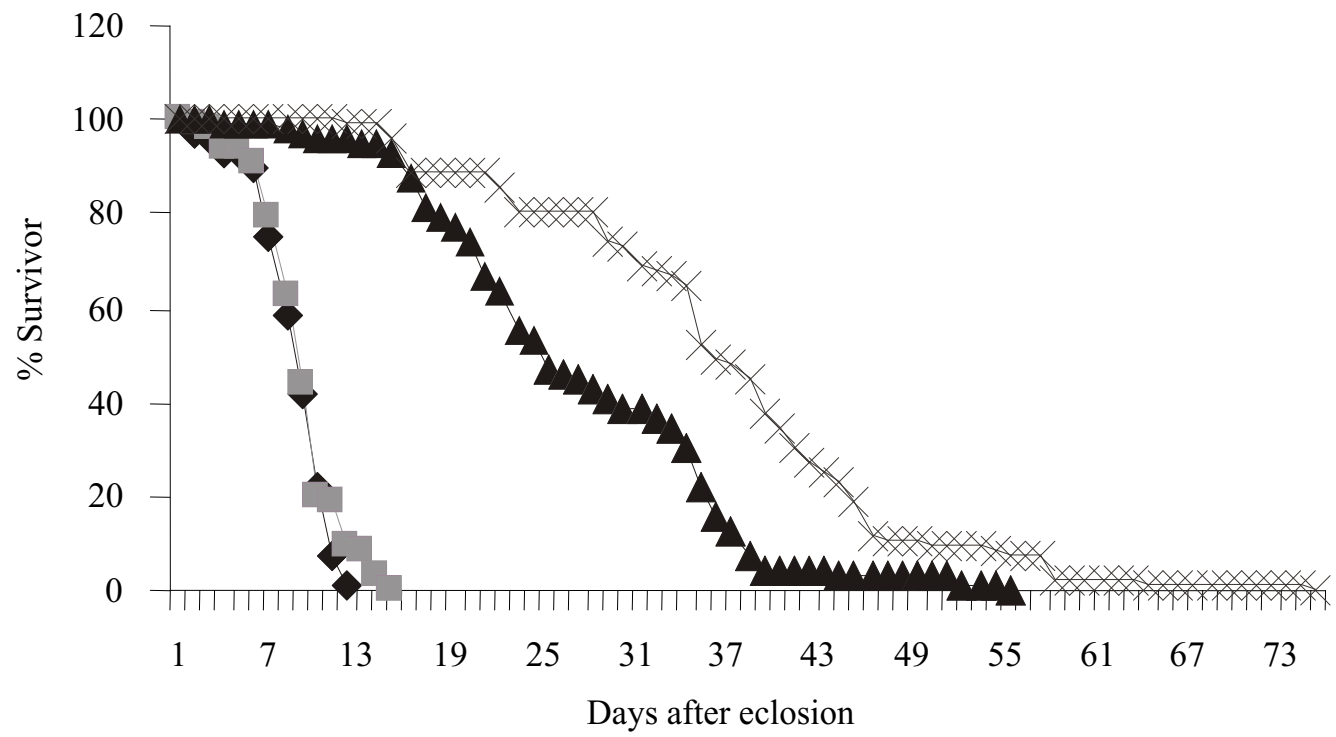

Fig 3 Percentage of adult survivors of Drosophila melanogaster (w1118) infected with the popcorn-effect inducing Wolbachia when untreated and treated with tetracycline and maintained at $29^{\circ} \mathrm{C}$. It's shows the life span of treated D. melanogaster is longer than that of untreated. $-: \%$ Survivor of untreated adult male w1118; $-\%$ Survivor of untreated adult female w1118; $-\%$ Survivor of adult male w1118 treated with tetracycline; $-\propto \%$ Survivor of adult female w1118 treated with tetracycline.

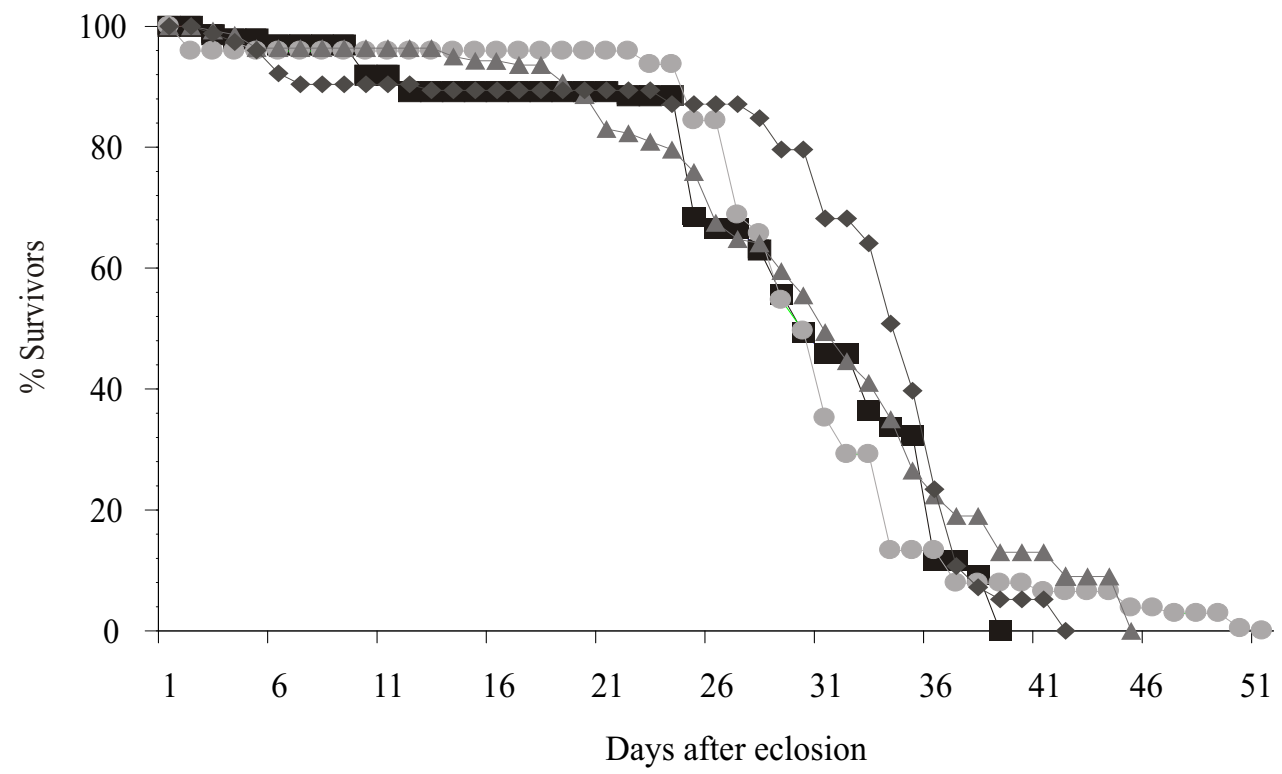

Fig 4 Percentage of adult survivors of Drosophila melanogaster (w1118) infected with the popcorn-effect inducing Wolbachia when untreated and treated with tetracycline and maintained at $20^{\circ} \mathrm{C}$. - : \% Survivor of adult untreated male W1118; - : \% Survivor of adult untreated male W1118; - - : \% Survivor of adult male W1118 treated with tetracycline; $\rightarrow$ : \% Survivor of adult female W1118 treated with tetracycline.

The potential of the popcorn-effect for the manipulation of vector insects have been repeatedly stressed, e.g., Bourtzis and Braig (1999). The ideal would be to express the early deaths associated with the popcorn-effect, for example, in Anopheles mosquitoes to prevent the transmission of malaria parasites. The finding reporter here that the popcorn-effect was in effect a laboratory artefact and was not expressed under physiological conditions put an early end to these hopes.

\section{REFERENCES}

Braig HR., Guzman H, Tesh RB, O'Neill SL 1994. Replacement of the natural Wolbachia symbiont of Drosophila simulans with a mosquito counterpart. Nature 367(6462): 453-55. doi:10.1038/367453a0.

Bourtzis K, Braig HR. 1999. The many faces of Wolbachia. In Raout D and Brouqui P, Editors. Rickettsiae and rickettsial diseases at the turn of the third millenium. Paris: Elsevier. 199-219. 
Breeuwer JAJ, Werren JH. 1993. Cytoplasmic incompatibility and bacterial density in Nasonia vitripennis. Genetics 135(2): 565-74.

Carrington LB, Hoffmann AA, Weeks AR. 2010. Monitoring long-term evolutionary changes following Wolbachia introduction into a novel host: the Wolbachia popcorn infection in Drosophila simulans. Proc R Soc B. 277(1690: 2059-2068. doi:10.1098/rspb.2010.0166.

Carrington LB, Leslie J, Weeks AR, Hoffmann AA. 2009. The Popcorn Wolbachia infection of Drosophila melanogaster: Can selection alter Wolbachia longevity effects? Evolution 63(10): 248-2657. doi:10.1111/j.15585646.2009.00745.x

Fujii Y, Kageyama D, Hoshizaki S, Ishikawa H, Sasaki T. 2001. Transfection of Wolbachia in Lepidoptera: the feminizer of the adzuki bean borer Ostrinia scapulalis causes male killing in the Mediterranean flour moth Ephestia kuehniella. Proc R Soc London B-Biol Sci. 268(1469): 855-59. doi: 10.1098/rspb.2001.1593.

Hoffmann AA, Turelli M, Simmons GM. 1986. Unidirectional incompatibility between populations of Drosophila simulans. Evolution 40(4): 692-701.

Jia FX, Yang MS, Yang WJ, Wang JJ. 2009. Influence of continous high temperatur condition on Wolbachia infection frequency and the fitness of Lipocelus tricolor (Psocoptera: Liposcelididae). Environt Entomol. 38 (5): 1365-1372. doi :10.1603/022.0380503

Kambhampati S, Rai KS, Burgun SJ. 1993. Unidirectional cytoplasmic incompatibility in the mosquito Aedes albopictus. Evolution. 47(2): 673-77. doi: $10.2307 / 2410079$

McGraw EA, Merritt DJ, Droller JN, O'Neill SL. 2002. Wolbachia density and virulence attenuation after transfer into a novel host. Proc Nat Acad Sci. USA. 99(5): 2918-23. doi: 10.1073/pnas.052466499.

McGraw EA, Merritt DJ, Droller JN, O'Neill SL. 2001. Wolbachia-mediated sperm modification is dependent on the host genotype in Drosophila. Proc R Soc London BBiol Sci. 268(1485): 2565-70. doi: 10.1098/rspb.2001.1839.
Min KT and Benzer S 1997. Wolbachia, normally a symbiont of Drosophila, can be virulent, causing degeneration and early death. Proc Natl Acad Sci. USA.94(20):10792-96. doi: 10.1073/pnas.94.20.10792.

Mouton L, Henri H, Charif D, Bouletreau M, Vavre F. 2007. Interaction between host genotype and environmental conditions affect bacterial density in Wolbachia symbiosis. Biol Lett. 3(2): 210-213. doi : 10.1098/rsbl.2006 0590 .

Stevens L. 1989. Environmental factors affecting reproductive incompatibility in flour beetles, genus Tribolium. J Invert Pathol. 53(1): 78-84. doi:10.1016/0022 2011(89)90076-1.

Stevens L, Wicklow DT. 1992. Multispecies interactions affect cytoplasmic incompatibility in Tribolium flour beetles. Am Nat. 140(4): 642-53.

Stouthamer R, Luck RF, Hamilton WD. 1990. Antibiotics cause parthenogenetic Trichogramma to revert to sex. Proc Natl Acad Sci. USA. 87(7): 2424-27. doi: 10.1073/pnas.87.7.2424.

Suh E, Mercer DR, Fu Y, Dobson SL. 2009. Pathogenicitty of life-shortening Wolbachia in Aedes albopictus after transfer from Drosophila melanogaster. App Environ Microbiol. 75 (24): 7783-7788. doi: 10.1128/AEM.01331-09.

Trpis M, Perrone JB, Reising, M, Parker KL. 1981. Control of cytoplasmic incompatibility in the Aedes scutellaris complex. J Heredity. 72(5): 313-17. doi: cgi/content/short/72/5/313.

Werren JH. 1997. Wolbachia run amok. Proc Natl Acad Sci. USA. 94(21): 11154-55.

Werren JH, Jaenike J. 1995. Wolbachia and cytoplasmic incompatibility in mycophagous Drosophila and their relatives. J Heredity. 75: 320-26. doi:10.1038/hdy.1995.140.

Yu Peng, John E, Nielsen, Cunningham JP, McGraw E A. 2008. Wolbachia Infection Alters Olfactory-Cued Locomotion in Drosophila spp. Applied and Environ Microbiol. 74: 3943-3948. doi:10.1128/AEM.02607-07. 